\title{
Archives, Manuscript Depositories, and Related Abbreviations
}

Most archives and manuscript depositories used in this book have their holdings divided into collections composed of individual files. PostSoviet collections also include an intermediary stage of "registers," into which collections are subdivided. Collections, registers, and files have unique numbers, while archives and depositories are denoted by their abbreviated names. Below the reader will find a list explaining those abbreviations, English translations and geographic locations.

$A A N$

$A G A D$

ANK

BJ

$B N$

d.

$D A K O$

$D A L O$

$f$.

$L N B$
Archive of Modern Records (Archiwum Akt Nowych), Warsaw.

Main Archive of Ancient Records (Archiwum Główne Akt Dawnych), Warsaw.

National Archive in Krakow (Archiwum Narodowe w Krakowie), Krakow.

Manuscript Section of the Jagiellonian Library (Sekcja Rękopisów Biblioteki Jagiellońskiej), Krakow.

Manuscript Collection of the Polish National Library (Zakład Rękopisów Biblioteki Narodowej), Warsaw. file (delo).

State Archive of the Kyiv Oblast (Derzhavnyi arkhiv Kyïus'koï oblasti), Kyiv.

State Archive of the Lviv Oblast (Derzhavnyi arkhiv L'vivs'koï oblasti), Lviv.

collection (fond).

Manuscript Collection of the Lviv National Vasyl

Stefanyk Scientific Library of Ukraine (L'vivs'ka natsional'na naukova biblioteka Ukraïny imeni $V$. Stefanyka), Lviv. 
MILZ Museum of the History of the Lviv Railroad (Muzei istorii L'vivs'koï zaliznytsi), Lviv.

TsDAHO Central State Archives of Public Organizations of Ukraine (Tsentral'nyi derzhavnyi arkhiv hromads'kykh orhanizatsii Ukraïny), Kyiv.

TsDAVO Central State Archives of Supreme Bodies of Power and Government of Ukraine (Tsentral'nyi derzhavnyi arkhiv vyshchykh orhaniv vlady ta upravlinnia Ukraïny), Kyiv.

TsDIAuL Central State Historical Archive of Ukraine in Lviv (Tsentral'nyi derzhavnyi arkhiv Ukraïny u Lvovi), Lviv. Op. $\quad$ register (opys, opis').

Rkps. Ossolin. Manuscript Division of the Ossolineum Library (Dziat Rękopisów Zakładu Narodowego im. Ossolińskich), Wroclaw.

RGIA Russian State Historical Archive (Rossiiskii gosudarstvennyi istoricheskii arkhiv), Saint Petersburg.

RGAE Russian State Archive of Economy (Rossiiskii gosudarstvennyi arkhiv ekonomiki), Moscow.

RGASPI Russian State Archive for Social and Political History (Rossiiskii gosudarstvennyi arkhiv sotsial'no-politicheskoi istorii), Moscow.

RGVIA Russian State Military-Historical Archive (Rossiiskii gosudarstvennyi voenno-istoricheskii arkhiv), Moscow.

Spr. file (sprava).

Sygn. file number (sygnatura).

Yad Vashem Yad Vashem Archives, Jerusalem.

Zesp. collection (zespót). 